\title{
Editor Note: Journal of Aquaculture Research \& Development Volume 8, Issue 2
}

\section{Mauro Lenzi*}

Lagoon Ecology and Aquaculture Laboratory (LEALab), Orbetello Pesca Lagunare Company, Italy

*Corresponding author: Mauro Lenzi, Lagoon Ecology and Aquaculture Laboratory (LEALab), Orbetello Pesca Lagunare Company, Italy, Tel: +39 3487 304274; Fax: +390564 867572; E-mail: lealab1@gmail.com

Rec date: Mar 27, 2017; Acc date: Mar 28, 2017; Pub date: Mar 30, 2017

Copyright: (c) 2016 Lenzi M. This is an open-access article distributed under the terms of the Creative Commons Attribution License, which permits unrestricted use, distribution, and reproduction in any medium, provided the original author and source are credited.

\section{Introduction}

There are scarcities of food worldwide, which is due to population explosion, illiteracy and dramatic changes in natural environment. Statistical data indicates that, 795 million people in the world sleeps at night with empty stomach, which justifies the need for food security and alternative food source [1]. It has been seen that, drastic fall in the farm products due monsoon failures, massive variation in the global temperatures, and shift in the raining patterns due to El Nino have continued to pose serious food shortage globally, prompting the policy makers to explore alternative strategies to ensure nutritious food to their population. Inexorably, climate change is mostly affecting the poorest regions in the world. Blessed with abundant vitamins, minerals and Omega 3 fatty acids, fish delicacies are sure to meet the evergrowing demand for nutritious food at an affordable cost. Fishing is an ancient trade, far older than the agriculture and it is dated back to Paleolithic age, when the trend possibly had started. Industrial pollution, urbanization, huge growth of the human population and climate change factors instigated due to anthropogenic reasons had a profound impact on the fish availability in the wild. Aquaculture is an intervention in the marine environment, involving stocking, feeding and protecting them from predators to increase the fish production. Aquaculture faces peculiar issues and challenges that need close attention, and, if conducted sustainably, it can mitigate the world problems of hunger.

The Journal of Aquaculture Research \& Development, Volume 8, Issue 2, has paid particular attention on the challenges to the environment due to aqua farming. The journal published well researched articles on the aspects like: treating the water contaminated due to aquaculture practices, morphological differences existed in the critically endangered fishing species Clupisoma garua in Bangladesh species, breeding and culture protocol involved in Hilsa fish production and management, and bacterial infection in the harvested fishes in the forms and the possible health hazards to the human, citing solutions to this effect are some of the prominently features articles, which explored the serious threats faced by the industry as a whole and offered valid solutions in mitigating them.

Aquaculture remained as an important subsidiary of agriculture and it is instrumental in feeding the global population by producing 66.6 million metric tons of fishes annually. Although, aquaculture is meeting $50 \%$ of global food and nutritional requirements, it is not without repercussions as it is contaminating the marine ecology. Omitoyin et al. [2], collected aquaculture wastewater from a catfish firm and treated it with duckweed, Lemna minor (Td) for two weeks. The performance and the growth of the culture of Nile tilapia raised in the treated water was compared with Oreochromis niloticus raised in water treated with bacteria Bacillus sp. O. niloticus raised in well water is considered as control group in this study. The research findings suggest that, Lemna minor could be used in fish culture with positive effect on water quality and growth performance.

Taking stock of the structure and the distribution of a particular fishing species is very important in the efficient implementation of the stock rebuilding programmes. Each fish variety demands a strategy and poor fish management strategies would result in dramatic changes in the biological attributes and productivity of a species. Nahar et al. [3], explored the morphological differences existed in the critically endangered fish species Clupisoma garua in Bangladesh. Once found abundant in the costal river side of Bangladesh and its neighboring countries like: India, Pakistan and Nepal. However, this fish species fall into a prey to the ever increasing anthropogenic and natural hazards. The study summarized that $C$. garua has different stocks in the selected rivers and no differences are traced in the fish stock from two rivers. The study found certain genetic and environmental factors and recommends further research to find the reasons for such changes. The present morphometric study serves as a guiding factor in implementation of appropriate mesh sizes in all selected rivers of the coastal region, which may help in sustaining this resource for future use.

Hilsa is much sought fish variety in the South Asian countries in general and Bangladesh in particular. Conservation of Hilsa fish variety demands a standard breeding and culture protocol process along with the present Hilsa management activities. Rahman et al. [4], discussed six breeding trials, where 13 pairs of selected Hilsa broods were used for the artificial breeding. Both eggs and milt were collected through stripping and then the eggs were mixed with the milt immediately. The fertilized eggs were transferred to a plastic jar for incubation. Despite taking enough measures like: providing mild water circulation, aeration and shade to protect penetration of direct sunlight to maintain congenial environment, the fertilized eggs did not survive and were filled with fungus within 24 hours. The artificial breeding of Hilsa exposed the challenges involved in this process. Hilsa grows very slowly and did not attain sexual maturity for artificial breeding. Hilsa has a typical life cycle and it is highly sensitive to oxygen depletion in water and sunlight and hence, artificial breeding of this species is far from success. The suggested onboard breeding trial as an important management measures for artificial breeding to produce mass seed production.

Increase in the world fish population is taking place due to complete shift in the fishing practices from capturing fishes in the wild, using nets to rearing them in the farms. In the year 2012, world aquaculture production attained all-time high production of 90.4 million tons, which included 66.6 million tons of edible fish and 23.8 million tons of aquatic algae. However, this practice is not free from challenges as fishes nurtured in this method are prone to affected by various diseases 
Citation: Lenzi M (2016) Editor Note: Journal of Aquaculture Research \& Development Volume 8, Issue 2. J Aquac Res Development 8: e113. doi:10.4172/2155-9546.1000e113

Page 2 of 2

due to the presence of pathogenic bacterial infections. Both the natural and the artificial food sources in the treated let water or the vertical transmission from brood stock are breeding disease, introducing pathogens in the aqua forms. According to the study, Vibrio anguillarum, a pathogen is responsible for 80,000 health disorders each year in USA and 52,000 cases are resulted in due to food contamination. Al-Taee et al. [5], have tried to isolate the potentially pathogenic species of Vibrio anguillarum in seven types of fish samples collected from fish farms located in different districts in Basra, Iraq. The study traced the presence of pathogenic Vibrio species nearly in all fish farms. The study suggests measures to the farm owners to mitigate pathogenic sources as it is posing several health risks to the human that consume the infected fish.

\section{References}

1. http://www.worldhunger.org/2015-world-hunger-and-poverty-facts-andstatistics/
2. Omitoyin BO, Ajani EK, Okeleye OI, Akpoilih BU, Ogunjobi AA (2017) Biological treatments of fish farm effluent and its reuse in the culture of Nile Tilapia (Oreochromis niloticus). J Aquac Res Development 8: 469.

3. Nahar A, Chaklader MR, Siddik MAB, Ilham I, Pham HD, et al. (2017) Stock structure of the critically endangered Clupisoma garua (Hamilton, 1822): An investigation based on discriminant analysis approach. J Aquac Res Development 8: 470 .

4. Rahman MA, Ahmed T, Pramanik MMH, Flura, Hasan MM, et al. (2017) On-board Breeding trial of hilsa (Tenualosa ilisha, Ham. 1822) and testing of larval rearing in Bangladesh. J Aquac Res Development 8: 471.

5. Al-Taee AMR, Khamees NR, Al-Shammari NAH (2017) Vibrio species isolated from farmed fish in Basra City in Iraq. J Aquac Res Development 8: 472 . 